\title{
THE PRELIMINARY GEOTOURISM STUDY IN PHETCAHBUN PROVINCE, THAILAND
}

\author{
Natapan PAUNGYA \\ Kasetsart University, Department of Earth Sciences, Faculty of Science, 50 Phahon Yothin Rd., \\ Khwaeng Lat Yao, Chatuchak, Bangkok 10900, Thailand, e-mail: Natapan.p@ku.th \\ Vimoltip SINGTUEN \\ Khon Kaen University, Department of Geotechnology, Faculty of Technology, 123 Mittapap \\ Rd., Nai-Muang, Muang District, Khon Kaen 40002, Thailand, e-mail: vimosi@kku.ac.th \\ Krit WON-IN* \\ Kasetsart University, Department of Earth Sciences, Faculty of Science, 50 Phahon Yothin Rd., \\ Khwaeng Lat Yao, Chatuchak, Bangkok 10900, Thailand, e-mail: kritwonin@yahoo.com
}

\begin{abstract}
Citation: Paungya, N., Singtuen, V., \& Won-In, K. (2020). THE PRELIMINARY GEOTOURISM STUDY IN PHETCAHBUN PROVINCE, THAILAND. GeoJournal of Tourism and Geosites, 31(3), 1057-1067. https://doi.org/10.30892/gtg.31318-541
\end{abstract}

\begin{abstract}
Phetchabun Province is situated in the lower northern region of Thailand. This province has many natural attractions with interesting cultures and traditions as a popular tourism destination. The geological signification of this area is in the collision zone between Shan-Thai plate and Indochina plate. Resulting in many outstanding geological diversities. This research focuses on geological features or ge osites as natural tourist attractions. Sixteen geosites were selected in Phetchabun Province consisting of waterfalls, potholes, cliffs, caves, columnar jointing, fossils localities, and many scenic viewpoints arising from tectonic plate evolution, weathering and erosion. Guidelines for geotourism development were analyzed. This is the first geotourism research study in this area, and presents geological data, recommended travel routes, an overview of the current situation and possible problems of promoting geosites as tourist attractions. Sustainable development of geotourism in Phetchabun Province will provide employment opportunities for the local population, respond to the currently increasing global ecotourism sector and increase geopark potential to be a national geopark.
\end{abstract}

Key words: Geoturism, Geosite, Phetchabun, Thailand, SWOT analysis

$* * * * *$

\section{INTRODUCTION}

Phetchabun Province is located in the northern-central-northeastern part of the country on the edge of the Khorat Plateau. Western, northern, and eastern areas are bounded by the Phetchabun mountain range as a horseshoe shape surrounding fertile plains in the central and south parts. The area represents the boundary between the Indochina and Shan-Thai plates collision in the Late Triassic and the plate boundary zone has been divided into the Loei-Phetchabun Fold Belt, the Sukhothai Fold Belt and the Nan Geosuture (Bunopas and Kong, 1982; Bunopas and Khositanont, 2008; Bunopas and Vella, 1983; Crawford and Panjasawatwong 1996; DMR, 2007a, 2009; Metcalfem, 1999; Singharajwarapan and Berry 2000). This process has resulted in diverse rock and mineral types, spectacular landforms and areas of outstanding natural geological beauty. The geological diversity has generated many different geosites such as spectacular landscape viewpoints, mountains, fossil sites, caves and speleothems, waterfalls and hot springs. Many interesting geosites are located within the boundary of the Phetchabun geopark that covers Nam Nao district, Lom Sak district, Mueang district and the National Park and Wildlife Sanctuary Area, while other outstanding geosites are distributed in other areas of Phetchabun Province. Tourists who visit Phetchabun can immerse themselves in nature and relax in a pristine and unspoiled environment. The area offers huge potential for geotourism as a form of natural area tourism that focuses on landscape and geology. Nowadays, the tourism influence businesses and the economy through the use of transportation, accommodation, food, products and services. If the tourism industry is supported and promoted by the government or private sectors, then businesses will show greater profits and the domestic economy will also benefit and grow as a result of the increasing availability of foreign exchange, local employment, and income distribution throughout the community. The Tourism Authority of Thailand (TAT) has promoted tourism using the logo "Amazing Thailand". This presents Thai traditional tourism and local experience appreciation with income distribution to the indigenous communities. In different regions, unique identities can generate new perspectives and act as a magnet for ecotourists.

Geotourism is an activity and form of alternative nature tourism that focuses on promotion, education, understanding, and appreciation of the geological value of landscapes in the area or geology-base tourism that become popular in many countries around the world (Dowling, 2011; Dowling and Newsome, 2005; Newsome and Dowling, 2017; Ruban, 2015). It can improve living standards and culture by providing employment for the local economy (Allan, 2013; Dowling, 2011; Newsome and Dowling, 2017) In other words, Geotourism was explained to the unique tourism form having a focus on geological feature and geoheritage (Stoffelen and Vanneste, 2015). Geotourism can bring positive results for the community such as raising awareness and establishing conservation consciousness in people through education, science, economics, and society by improving living standards and the local economy and also increasing respect for nature (Ciftci and Güngör, 2016; Dowling, 2011; Hose, 2000, 2008; Hose, 2011; Lazzari and Aloia, 2014). The keys to sustainable tourism development are increasing the profits and benefits for local communities, cultural activities in order to local recognize and create a positive attitude towards geotourism (Farsani et al., 2014; Shahhoseini et al., 2017). The term geotourism was first coined in the United Kingdom at university research level and later became widely accepted and used in Europe and other countries (Dowling and Newsome, 2005; Hose, 1995, 2000, 2008; Ruban, 2015). Geosites designate areas of spectacular geological, geomorphological and palaeontological features with in-situ and exsitu occurrence and may also display high value geodiversity such as fossils, mineral sites, landforms, soil feature, ground formation, caves, and grottos (Brilha, 2016, 2018; Gray, 2004; Panizza, 2001, Wimbledon, 1996). Geosites result from the evolution of the earth's crust or geological processes and display outstanding scientific, historical, economic and aesthetic geological features.

\footnotetext{
${ }^{*}$ Corresponding author
} 
Geotourism and geological knowledge are listed as an important part of the geopark compositions up to 30\% (Singtuen et al., 2019). Therefore, the development of geotourism is an important driver in a geological park management. Geotourism and geopark are one model of sustainable development maybe improve the environment and geoheritage consrvation (Gray, 2019). Consequence result, Geopark establishing can support local products, local food and local accommodations (Singtuen et al., 2019).

In past decades, geotourism research mainly involved Europe but Asian countries such as China, Japan, and Malaysia are now attracting increasing geotourism publicity (Ruban, 2015). The sample geotourism research in Thailand described the geodiversity of geosites in Chiang Mai, Chaiyaphum, Buriram, Ubon Ratchatani Province and Samui Island along with assessments for future conservation management (Singtuen and Won-In, 2018, 2019; Singtuen et al., 2019; Nazaruddin, 2020). Here, geosites in Phetchabun Province are described and classified. Prospective geotourists need to understand the concepts of geological attractions. The Petchabun Province public relations department may find this information useful for efficient conservation and geotourism development in the future. Geotourism also conforms with the Thailand tourism campaign in the field of local experience appreciation and traditional tourism.

\section{MATERIAL AND METHODS}

The materials used in this study comprised literature related to the research topic, a geological map of Phetchabun Province scale 1:100000, the Google map website, and a camera for photography. Information concerning the selected geosites was analyzed and classified into groups of geological features for fieldwork study by category of Gray (2004) and Newsome (2012). Geoconservation and geotourism development were qualitatively assessed for strengths, weaknesses, opportunities, and threats using the SWOT analysis technique (Gurel, 2017). Suitable travel routes in Phetchabun Province were mapped. The material and methods are modified form Singtuen and Won-In (2018a, 2018b, 2019) and Nazaruddin (2020).

\section{RESULTS AND DISCUSSION}

\section{Inventory and characterization}

Interesting geosites in Phetchabun Province include areas in Nam Nao district, Lom Sak district, Muang district, and Wichian Buri district. Explanations of geosite characterizations are described below.

Nam Nao National Park comprises the areas of Nam Nao district and Lom Sak district. Nam Nao district has many kinds of geosites as well as viewscapes and geo-trails. Nam Nao cave or "Phu Nam Rin" (Figure 1) is a Permian limestone cave (Figure 16) of Pha Nok Khao rock formation located in the northern part of Nam Nao National Park. It is the third-longest cave in Thailand with a length of 9,817 meters but only 418 meters are accessible for visitors (DMR, 2007b, 2009; Ellis, 2006; Fontaine et al., 2001; Fontaine et al., 2002). This limestone cave has active, continuously accumulating stalagmites and stalactites. Fusulinid and Brachiopod fossils have been found in the cave (Hada et al., 2015). Caves are formed by water erosion of permeable carbonate and sulfate rocks such as limestone, dolomite, marble, and gypsum over a very long time. The water permeates through the rock and initiates a slow dissolution process (Davies and Morgan, 1991). The Pha Nok Khao rock formation dates from the lower-middle Permian period and consists of dark-gray chert (chert nodules in limestone), gray limestone, mud cracks and shale. Nam Nao Archosaur Footprints Cliff (Figure 2a-2b) is famous for the ancient fossil footprints found there with 2-2.5 feet long steps. These lithified footprints can be seen on the mudstone and shale bed in late Triassic of Huai Hin Lat Formation (Figure 16) (DMR, 2007b; Khositanont and Khositanont, 2018). The cliffs slope at around 60 degrees for a distance of more than 100 meters (Saenyamoon et al., 2005). The footprints are thought to have been made by an Archosaur or ancient ancestors of crocodiles.
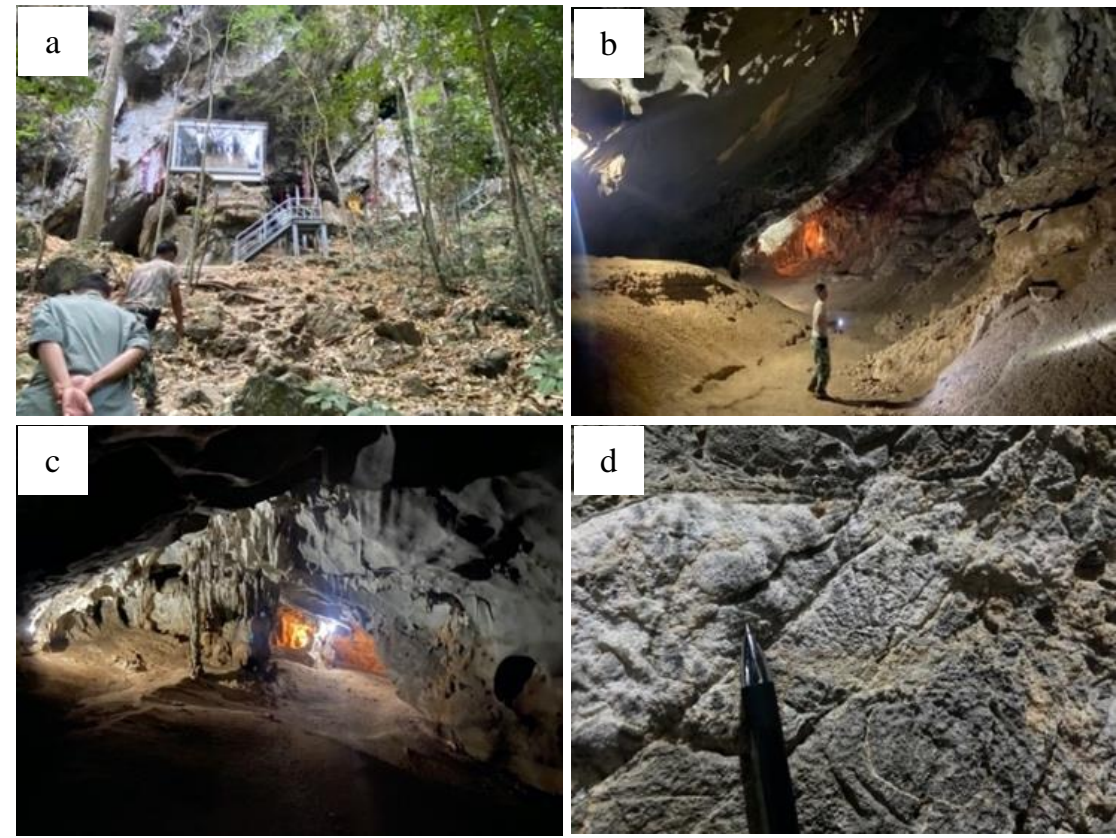

Figure 1. Nam Nao Cave a) The cave entrance; b) The cave pathway; c) The cave chamber and d) Brachiopods fossil

Nam Nao Canyon comprises a large cliff of red-brown sandstone and shale in a flat rock formation (Figure 3a-3c) (DMR, 2007b). The cliff has large folds and cracks which formed as a part of Phetchabun active fault. Long ago, the earth's crust was uplifted as a result of pressure from moving continental plates that produced a folded structure. Over many years, weathering and erosion by streams flowing through the area formed a canyon with steep sides around 200 meters high (Khositanont and Khositanont, 2018). Shale layers are more easily eroded than sandstone layers, resulting in visual erosion as streaks on the cliff face. During the rainy season, a stream flows through the gorge.

There is a small waterfall in the vicinity called "Nakkarat Tadmok Waterfall" (Figure 3d). At Loei Dun (Figure 4) in the northeastern part of Nam Nao district at the boundary of Loei and Phetchabun Provinces there are potholes in the red-brown sandstone (DMR, 2007b; 
Sakha, 2018) and also found siltstone and pebbly sand in Nam Phong Formations (DMR, 2020). Potholes in the bedrock were caused by erosion over many millions of years by the abrasion of sediments borne by strong swirling water as whirlpools and eddies, like the occurrence of Sam Pan Bok geosite in Ubon Ratchathani, Thailand and other geosites (Singtuen and Won-In, 2019; Wang et al., 2009; Zhong et al., 2002). The potholes can be clearly seen during the dry season, but they are covered by water flow in the rainy season.

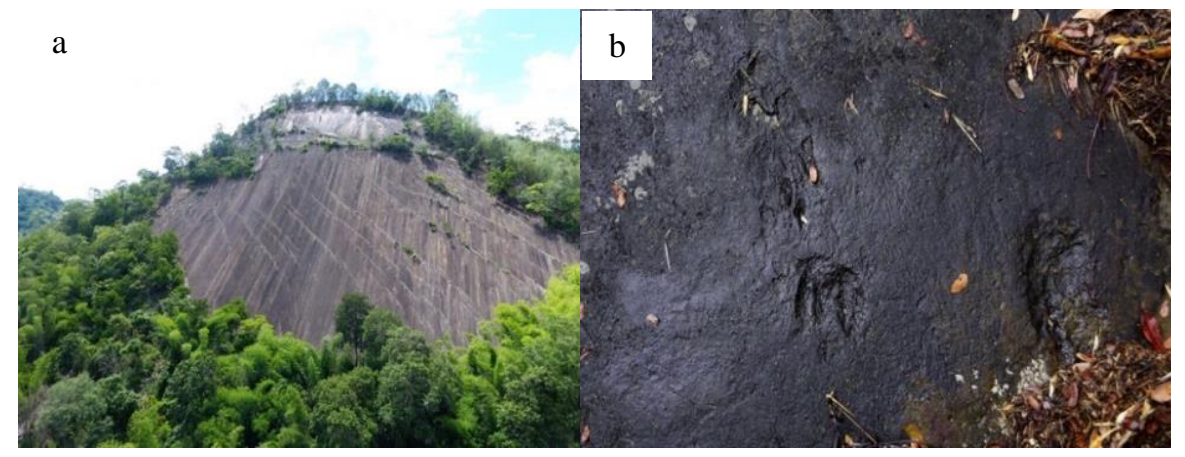

Figure 2. a) Archosaurs footprint cliff; b) Archosaurs footprint (Figures permitted by Phetchabun Geopark director)
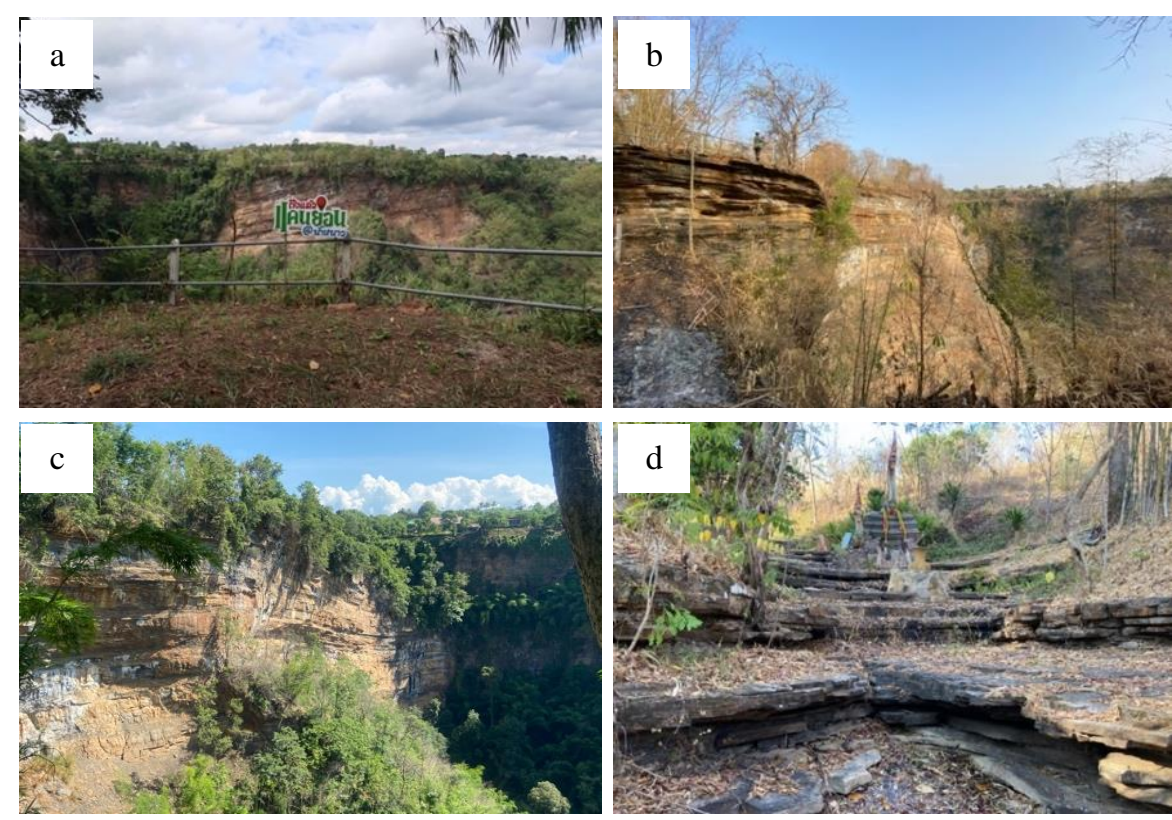

Figure 3. Nam Nao Canyon a) Site label; b) Viewpoint; c) Cleary structure of rock and d) Nakkarat Tadmok waterfall
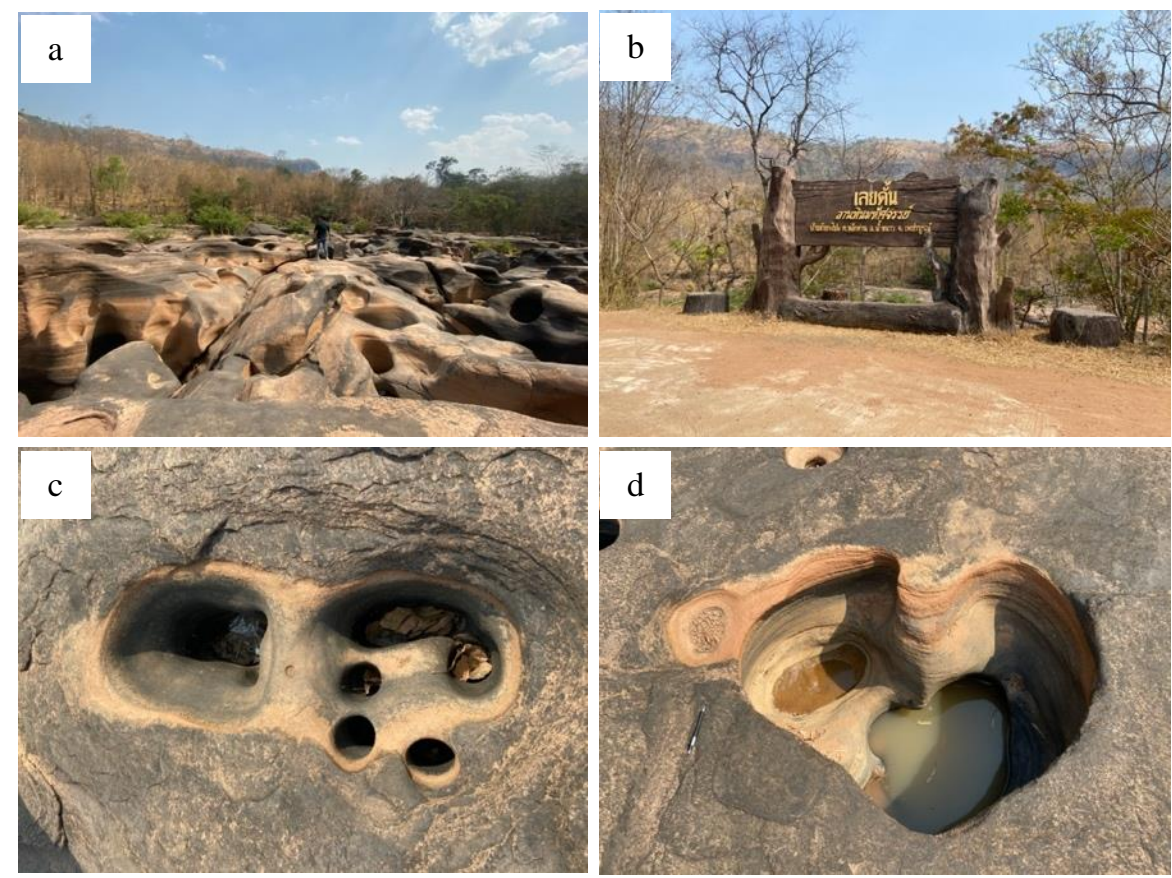

Figure 4. Loei Dun a) Wide viewpoint; b) Geosite label; c) and d) Various pothole shape in geosite 
In Lom Sak district, the Ruesi Sombut Cave (Figure 5a-5b) was formed in the geological past in lower Permian limestone through sediment dissolution that date from 286-258 million years ago. The Pha Nok Khao rock formation group is composed of massive gray limestone (DMR, 2007b, 2009). Stalactites and stalagmites can be seen in the cave but not active. This cave has an important military history and was used as the hidden treasure location of the Thai Government B.E. 2487 (Tourism Authority of Thailand, 2011). Currently, the cave is under monastic management and there is a Buddha statue in the small entrance chamber.
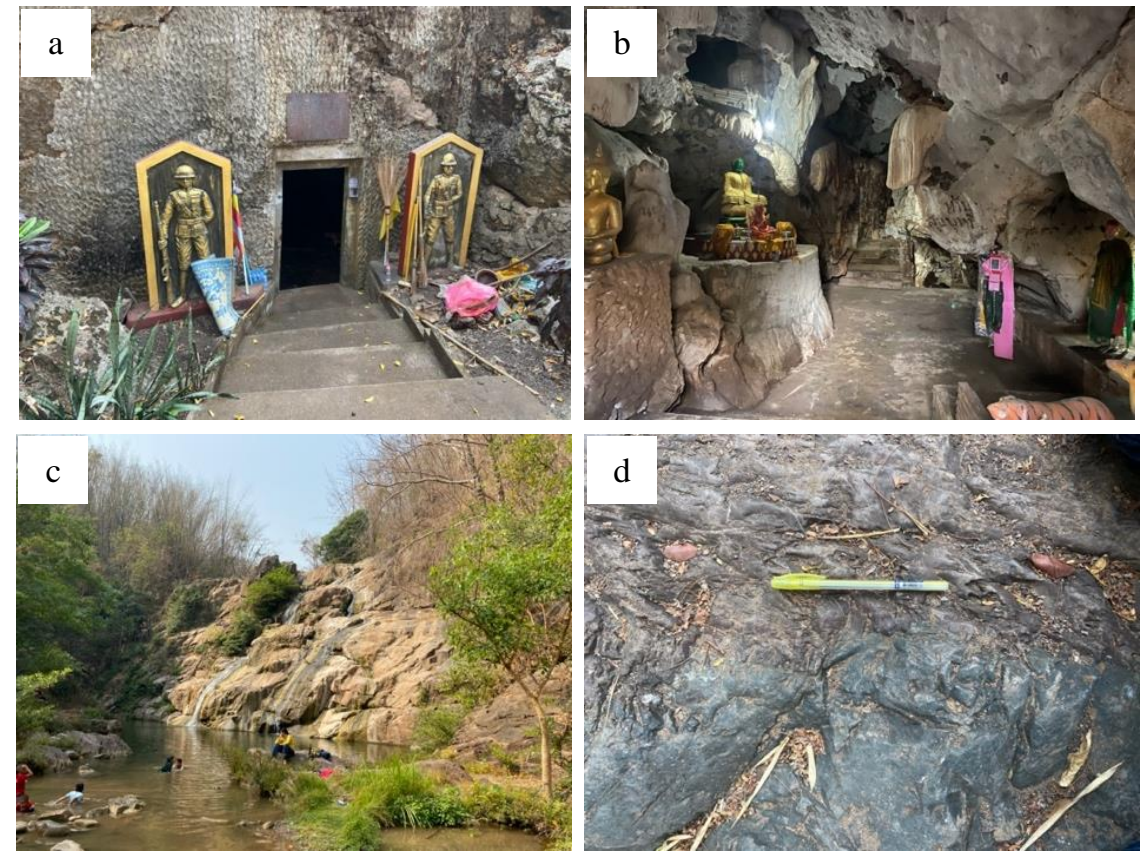

Figure 5. a) The Ruesee Sombut cave entrance; b) The Ruesee Sombut cave chamberconsisting of Religious objects; c) The Tarn Thip waterfall and d) Dark-gray mudstone and red-brown sandstone
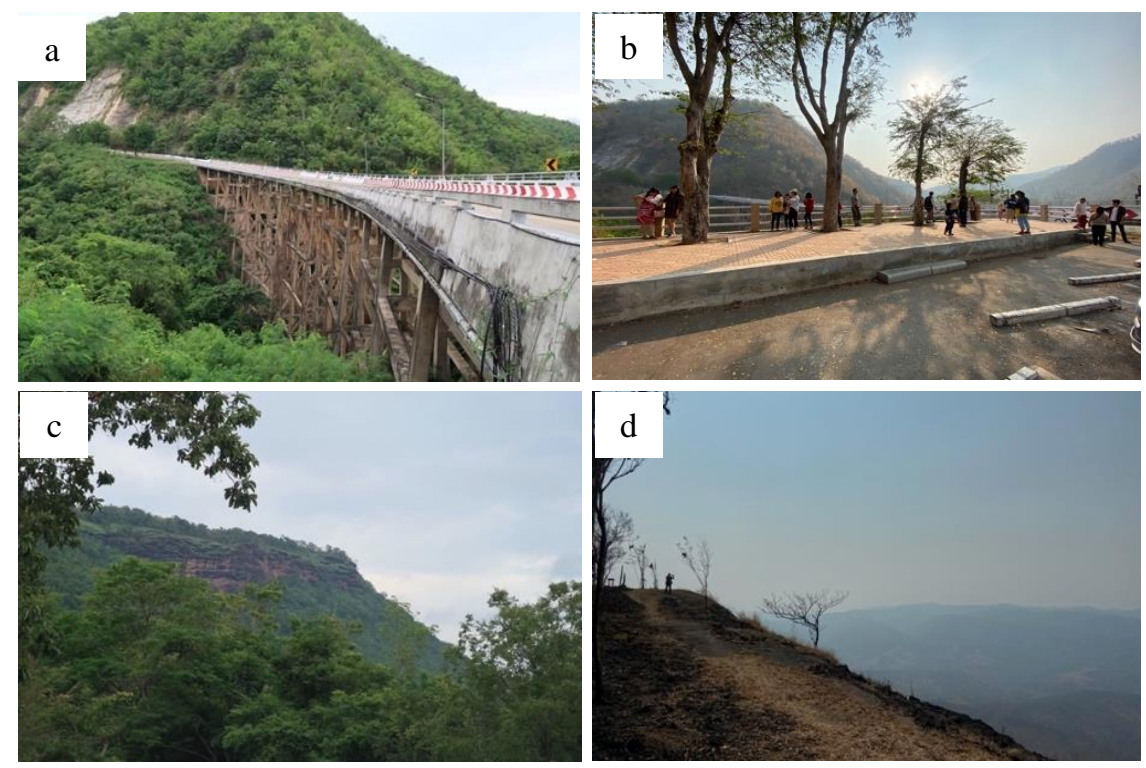

Figure 6. a) Huai Tong Bridge viewpoint; b) Haui Tong Bridge car parking;

c) Pha Daeng Continental Margin Cliff from roadside perspective; d) The top of Pha Daeng Continental Margin Cliff

The Than Thip Waterfall (Figure 5c-5d) flows over fine-grained sandstone and mudstone, with a height of 26 meters and a width of 30 meters. The rock characteristics are shale, dark-gray mudstone and red-brown sandstone that date from 230 million years ago in upper Triassic, Huai Hin Lat formation (DMR, 2007b, 2009). The colors of the rocks indicate the different sediment types. The waterfall is the headwaters of the Huay Nam Kla River in Lom Sak district. There is a natural trail to the waterfall around 400 meters long through virgin deciduous dipterocarp forest and dry evergreen forest. The Huai Tong Land Connection Bridge is located on Lomsak-Chumpae route (Figure 14). This is the highest bridge in Thailand with 50 meters of bunting (Figure 6a-6b). This area represents the boundary between the collision of the Indochina plate in the east and the Shan-Thai plate in the west as the central Sukhothai Fold Belt, Nan Suture, and Loei Fold Belt (Bunopas and Kong, 1982).

A viewpoint overlooking the bridge presents a truly breathtaking vista. The Pha Daeng Continental Margin Cliff is formed of red sandstone (DMR, 2007b) and located at the boundary of Phu Pha Daeng Wildlife Sanctuary on Lomsak-Chumpae route (Figure 14). To view the bottom of the cliff you can walk up to the top. The viewpoint presents an attractive setting as a cliff ridge extending into the sky for a charming sunset.

This cliff was formed by the Phetchabun fault under the influence of the Indochina and Shan-Thai plates (Khositanont and Khositanont, 2018). The Pha Deang Shrine is located below the cliff (Figure 6c-6d). The Pha Hong Scenic area at the boundary of Nam Nao National Park in part of Lom Sak district has excellent viewscapes. The site offers a sunset viewpoint with a flock of bats on a Permain limestone mountain 
(DMR, 2007b). From the top viewpoint you can see the topography of the mountain range on the west side of Phetchabun Province and suture zones between Shan-Thai plate and Indochina plate (Khositanont and Khositanont, 2018; Sakha, 2018). The viewpoint is 400 meters from the Lonsak-Chumpae route (Figure 14) with a climb of 259 stair steps in gnarled and sharp rock. Ensure that you are well prepared and ready for walking and hiking (Figure 7a-7b). Another outstanding geosite in Lom Sak district is Non Hua Lon or Ban Tew Canyon in Ban Tew subdistrict. Non Hua Lon is a natural canyon formed in siltstone and sandstone layers that were weathered and eroded by rainfall and stream waters (Figure 7c-7d) (DMR, 2007b). This area has characteristics similar to Phae Muang Phi Park in Phrae Province. The various rock sizes indicate different transportation distances in the past (Sinsakul, 2535). Some parts show laterite rock formations.
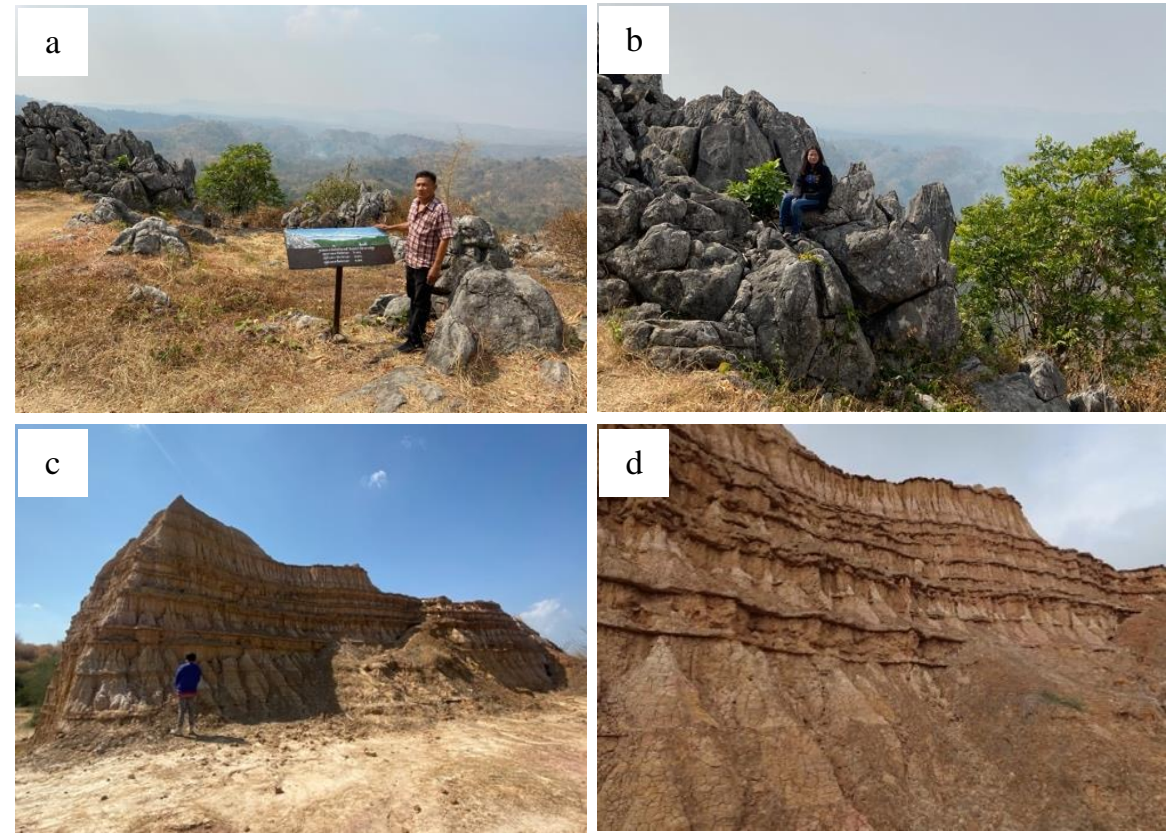

Figure 7. a) Pha Hong Scenic Area and information label; b) Limestone mountain in Pha Hong Scenic Area; c) and d) Non Hua Lon: the weathering and erosion phenomenon
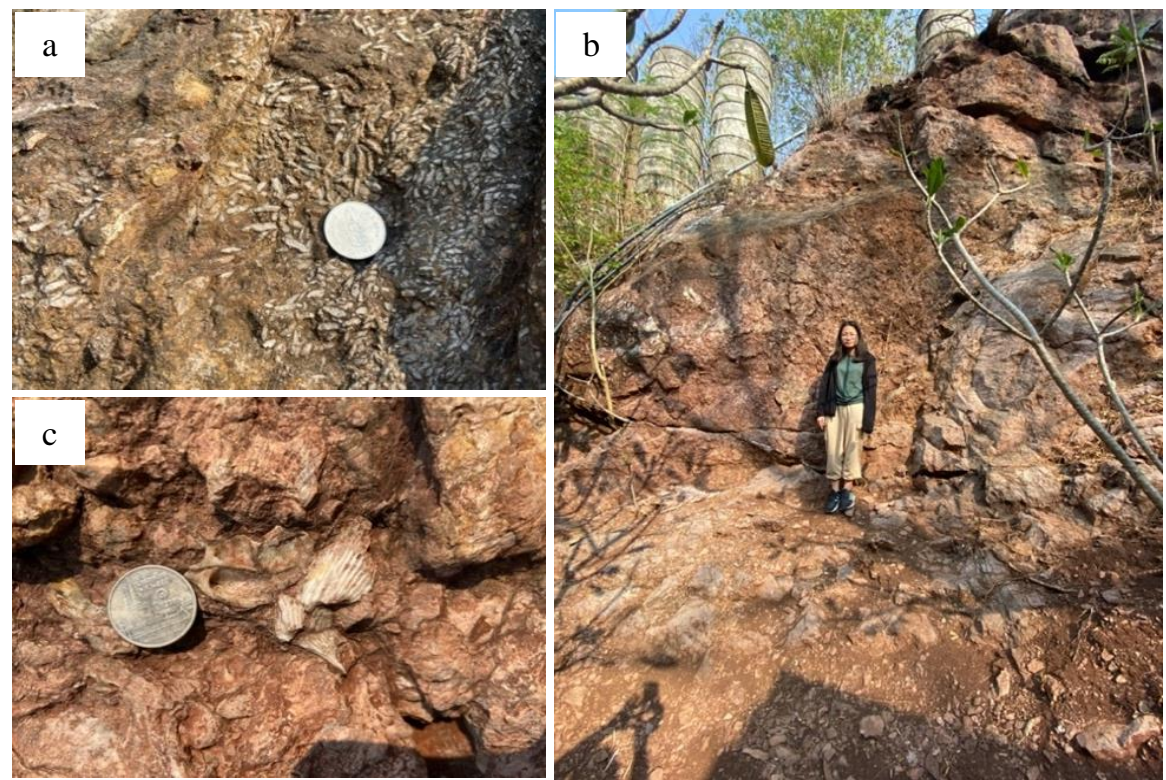

Figure 8. Fossils site in Temsip abbey a) Fusulinid fossil b) Fossils mountain and c) Brachiopod fossil

Muang district has a famous fossil site at Tem Sip abbey (Figure 8a-8c). The area is protected by the abbey office. The fossils are found in fossiliferous limestone rocks from the Permian period (Figure 16) (Dawson, 1978; DMR, 2007b; Chonglakmani and Sattayarak, 1979; Hinthong, 1985; Wielchowsky and Young, 1985). Major fossil types are Fusulinids and Brachiopods. These fossils are also found in the limestone rocks in nearby areas such as Nam Nao Cave in Nam Nao district and Phu Nam Yod district in Wichian Buri district (Hada et al., 2015).

Wichian Buri district is mostly composed of open plains with some geosites. Hexagonal rock pillars are formed of porphyritic dark-gray basaltic rock as 11 million years old columnar joints (DMR, 2007b; Charoensuk, 2016; Suthirat et al., 1994). These formations resulted from lava cooling. Long ago, lava flows covered the area and the top surface rapidly cooled and contracted with increasing stresses in all directions. Most columns were formed as hexagonal systems as the optimal development (Gray, 1986). These rock pillars rise up perpendicular to the earth's surface. Over millions of years, geological processes such as impacts from the Phetchabun fault, weathering, and erosion altered the earth's crust in this area. Volcanic rocks in this area also include important petroleum reservoirs in Thailand (Kosuwan, 1995; Limtrakun et al., 2013). Nearby, the igneous rock pillar waterfall, "Sab Plu Waterfall" or "Yang Sao Basaltic Columnar Joint Waterfall" is the only basaltic pillar rock waterfall in Thailand (Figure 9). 

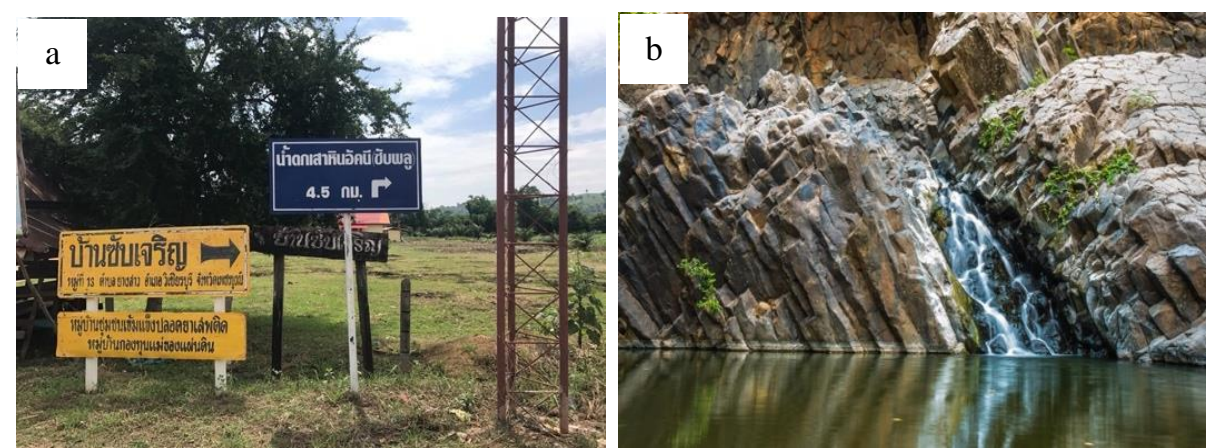

Figure 9. a) Sab Plu waterfall label and b) Cleary columnar joint in geosite (Figures permitted by Phetchabun Geopark director)
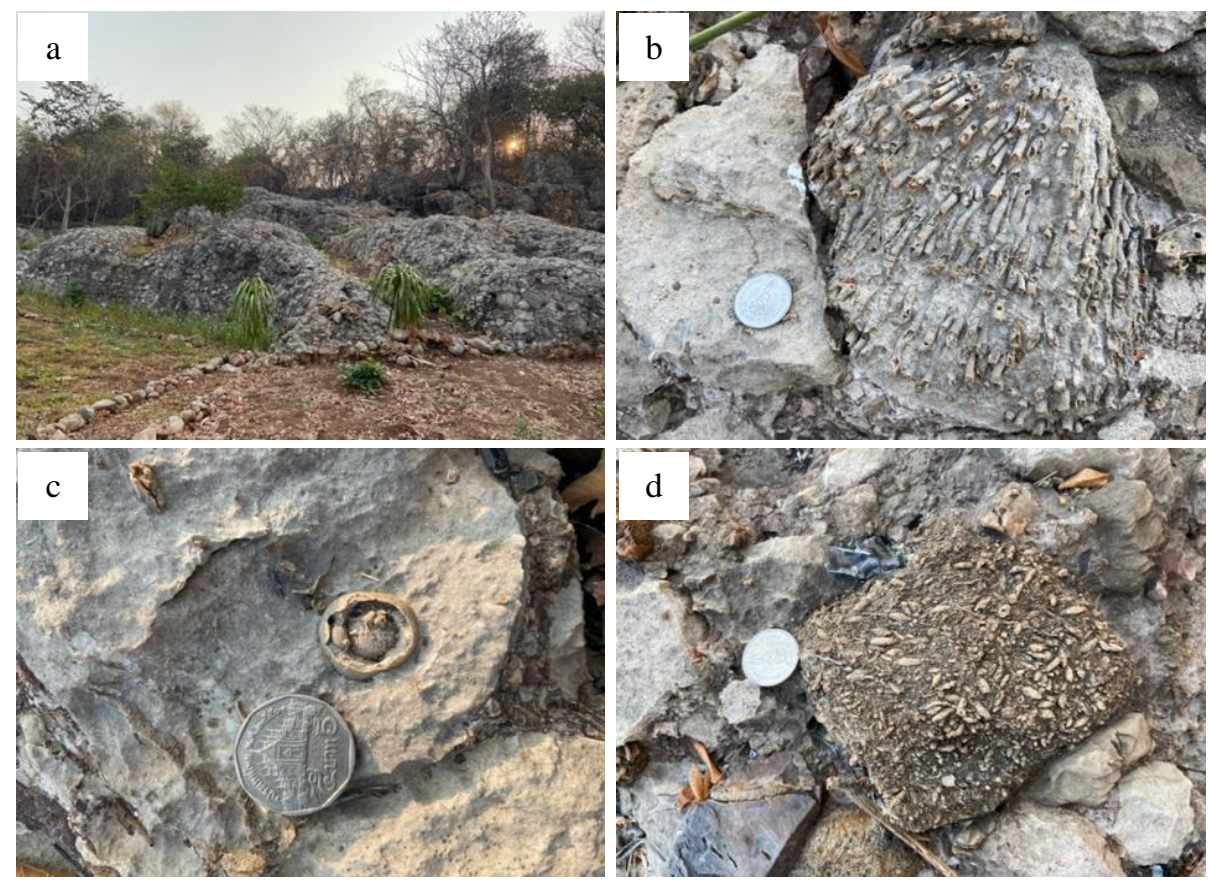

Figure 10. a) Phu Nam Yod Fossils Site; b) Corals fossils; c) Gastropod fossils and d) Fusulinids fossils
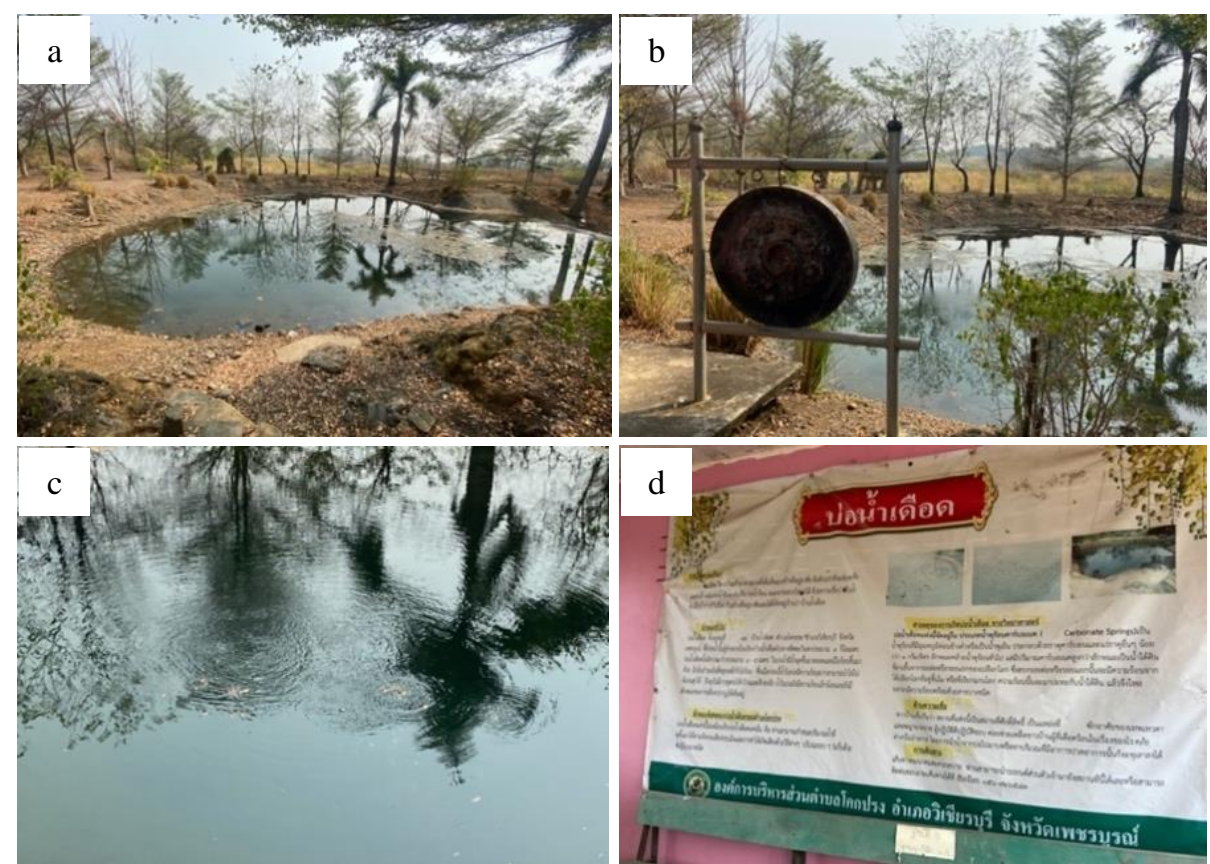

Figure 11. a) and b) Bor Nam Dued Hot Spring; c) The air bubbles that pop up from under the water and d) Information label

The Phu Nam Yod Fossil Site in Phu Nam Yod sub-district, Wichian Buri district (Figure 10) presents clear evidence that this area was once a continental shelf under an ancient sea some 240 million years ago during the Permian Period (DMR, 2007a, 2007b). The limestone rocks comprise breccias and fossils of corals, fusulinids, gastropods, bivalves, ammonites and radiolarians as single-celled colonial protozoa (Chonglakmani and 
Fontaine, 1990; Hinthong, 1985). Hot springs can be found at Kok Prong Amazing Hot Spring or "Bor Nam Dued" (Figure 11). Hot spring water contains high amounts of carbonate compounds and often has a faint smell of sulfur (Raksaskulwong, 2015). The heat is generated from the high geothermal gradient and igneous rocks in the area which age around 250 million years old (DMR, 2007b, 2009). The hot spring exudes water at temperatures between 30 and 50 degrees Celsius with $\mathrm{pH}$ ranging 7.5 to 9 as weakly alkaline (Subtavewung et al., 2005). One remarkable characteristic is the boiling sponge that springs up when sound occurs because the sponge in the pool is affected by sound vibrations. Previously, the sound was given out from a large gong (Thai musical instrument) used as a test machine. At a nearby site in Kok Prong subdistrict there are fossiliferous gastropod beds (Bellamya sp.) deposited around 13 million years ago (DMR, 2009; Sakha, 2018) (Figure 12).
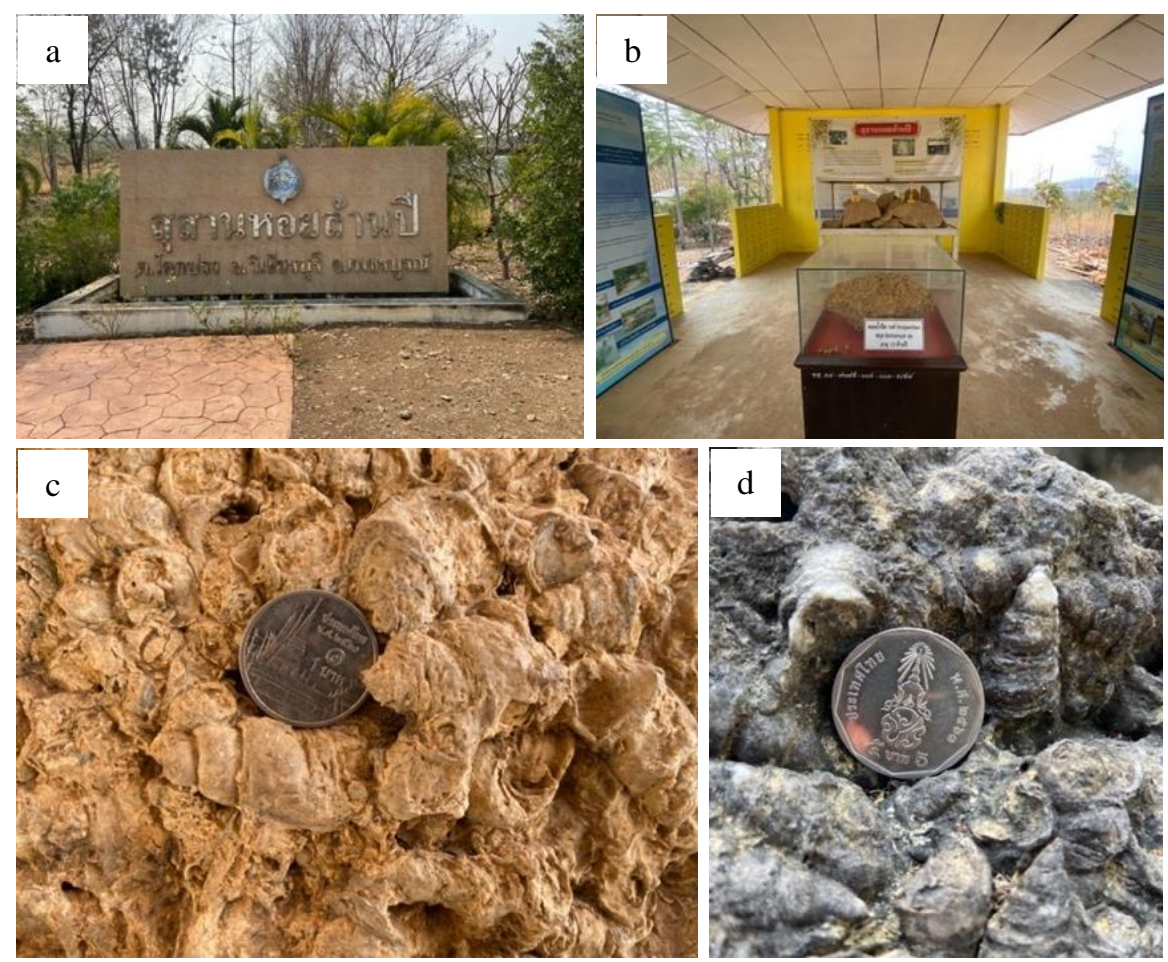

Figure 12. a) Kok Prong Gastropod fossils site; b) Fossils exhibition building c) and d) Various gastropod size

Table 1 Classification with major category and geodiversity of geosite in geotourism ${ }^{1}$ Newsome et al., $2012 ;{ }^{2}$ Gray, 2005

\begin{tabular}{|l|l|l|l|}
\hline \multicolumn{1}{|c|}{ Geosite } & \multicolumn{1}{c|}{ Major category ${ }^{1}$} & \multicolumn{1}{c|}{ Geodiversity ${ }^{2}$} \\
\hline Nam Nao Ancient Cave & Cave and speleothems & Rock, mineral, fossil, landform/landscape, process \\
\hline Nam Nao Archosaur Footprints Cliff & Weathered and erode landforms, Fossil & Rock, Landform/landscape \\
\hline Nam Nao Canyon & Weathered and erode landforms, Canyon & Rock, Landform/landscape \\
\hline Loei Dun Pothole & Weathered and erode landforms & Rock, Landform/landscape \\
\hline Ruesi Sombat Cave & Cave and speleothems & Rock, mineral \\
\hline Tarn Thip Cascade & Waterfall, Rock outcrop & Rock, Landform/landscape \\
\hline Non Hua Lon & Weathered and erode landforms, Canyon, Soils & Rock, Landform/landscape, soil \\
\hline Huai Tong Land Connection Bridge & River valleys & Rock, Landform/landscape \\
\hline Pha Daeng Continental Margin Cliff & Weathered and erode landforms, Mountain & Rock, Landform/landscape \\
\hline Pha Hong Scenic Area & Karst environment, Mountain & Rock, Landform/landscape \\
\hline Temsip Fusulinid Fossil Site & Weathered and erode landforms, Fossil & Rock, mineral, fossil, landform/landscape, process & Muang \\
\hline $\begin{array}{l}\text { Yang Sao Basaltic Columnar Joint } \\
\text { Park and Cascade }\end{array}$ & Volcanics landforms, Rock outcrop, Waterfall & Rock, Landform/landscape \\
\hline Phu Nam Yod Fossils Site & Weathered and erode landforms, Rock outcrop, Fossil & Rock, mineral, fossil, landform/landscape, process \\
\hline Kok Prong Gastropod Fossils Site & Weathered and erode landforms, Rock outcrop, Fossil & Rock, mineral, fossil \\
\hline Kok Prong Hot Spring & - & Rock, process \\
\hline
\end{tabular}

Table 2. Potential of geopark in Phetchabun Province analyzed by SWOT analysis

\begin{tabular}{|c|c|}
\hline SWOT & Remark \\
\hline Strength & $\begin{array}{l}\text { - Various geodiversity, and natural diversity } \\
\text { - } \text { Good transportation route, and car park } \\
\text { - } \\
\text { - Tood protection from geopark and quality organization } \\
\text { - Good homestay and other accommodation networks }\end{array}$ \\
\hline Weakness & $\begin{array}{l}\text { - Some sites benefit of very inferior accessibility such as Nam Nao Archosaur Footprints Cliff and Yang Sao Basaltic } \\
\text { Columnar waterfall with dangerous gravel path. } \\
-\quad \text { Some direction signs have old and faded characters. } \\
\text { - } \\
\text { - Some people in the area are still unable to provide suggestions on how to access the geosite. } \\
\end{array}$ \\
\hline Opportunity & $\begin{array}{l}\text { The budget is supported by government and external agencies. } \\
\text { - The areas that receive attention from the education part such as field trip in geopark and research. } \\
\text { - Education department cooperation and research }\end{array}$ \\
\hline Threat & $\begin{array}{ll}- & \text { Disaster such as wildfire } \\
- & \text { Forest invasion of human } \\
\end{array}$ \\
\hline
\end{tabular}



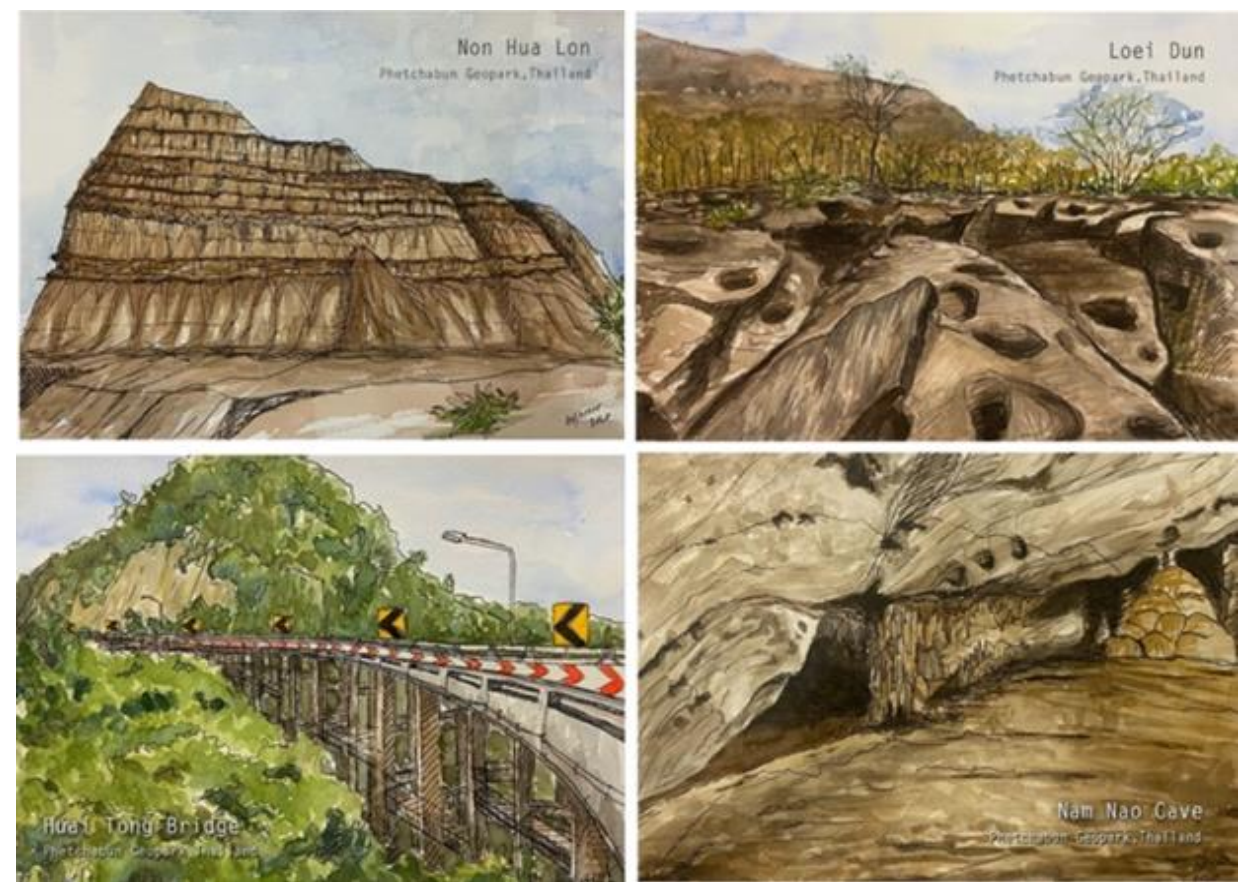

Figure 13. Watercolor painting of some geosites in Phetchabun Geopark for Postcards and Souvenirs painted by N. Paungya (The first author of this paper)

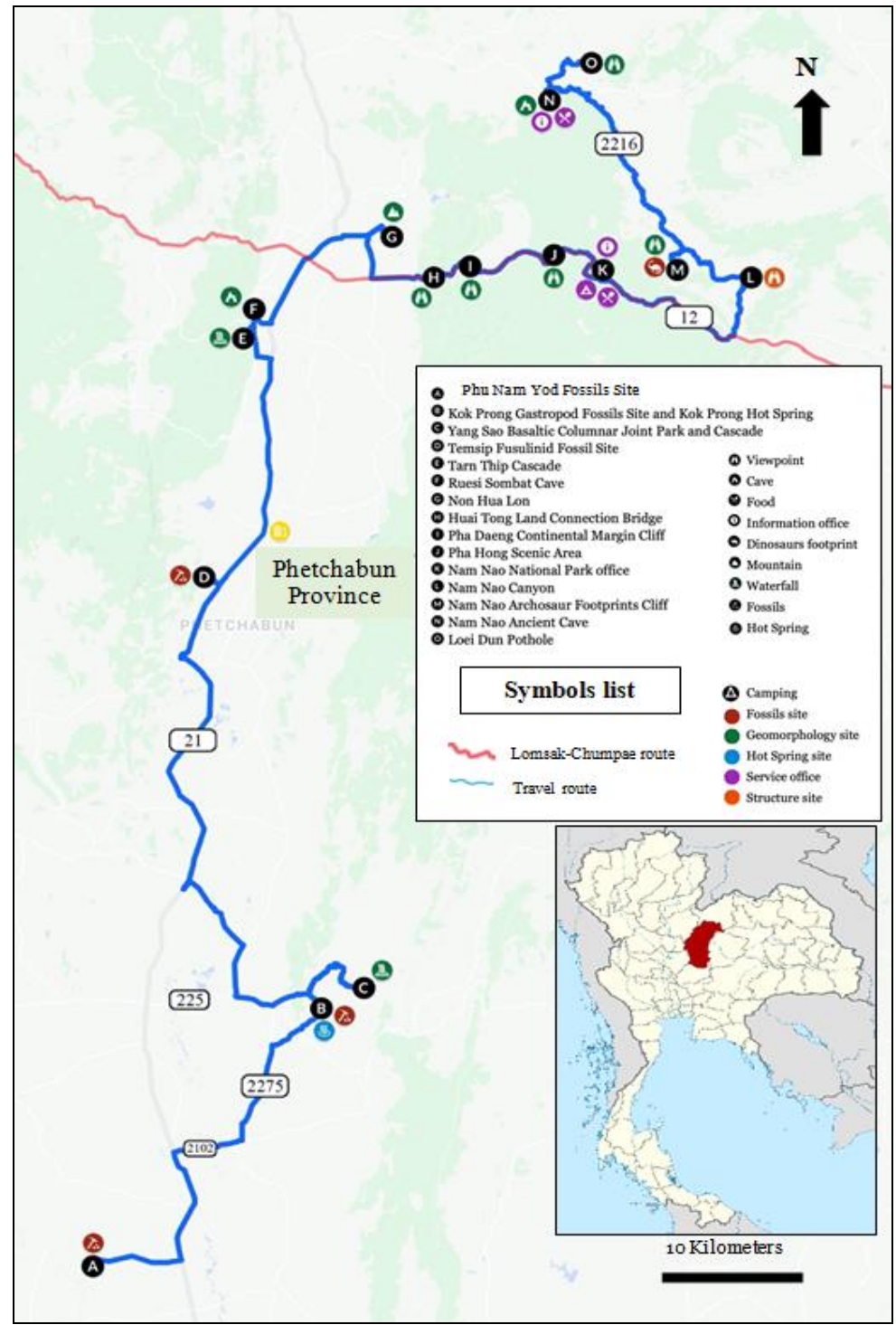

Figure 14. The travel route of selected geosites in Phetchabun Province
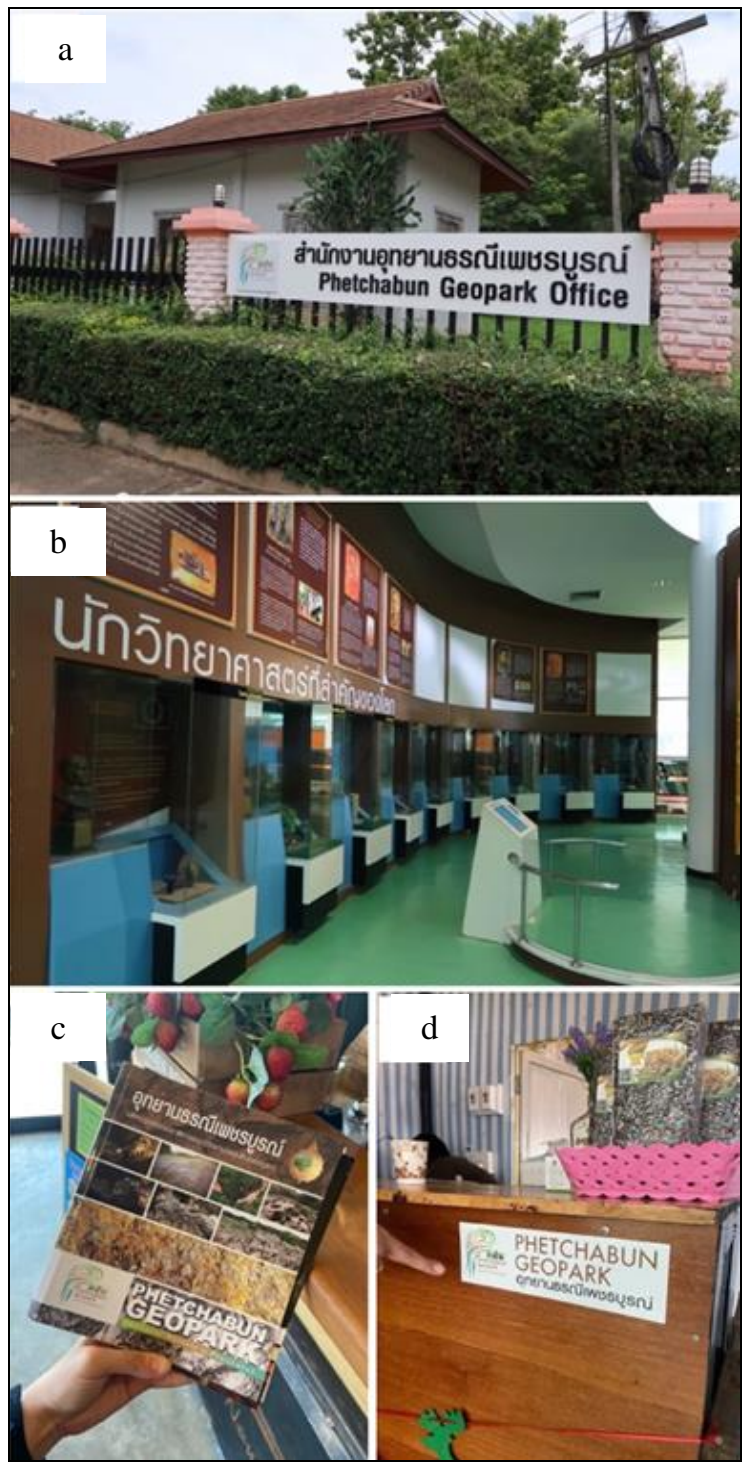

Figure 15. a) Phetchabun Geopark office; b) Inside the Nong-Naree Science Park; c) Tourist attraction books and d) Example of geopark public relation in local restaurant 


\section{Classification}

Table 1 classifies the attractions in Phetchabun Province. The data consist of natural geosites with rock process geodiversity, landforms/landscapes, minerals, and fossils following the concept of Gray (2005). Types of attraction are categorized according to the major subsets of Newsome et al., (2012). This preliminary data gathering presents and classifies geo-attraction sites in a more systematic manner.

\section{Assessment}

The selected geosites were first qualitatively assessed using SWOT analysis for more efficient management in the future (Table 2). SWOT analysis factors consist of strength $(\mathrm{S})$, weakness $(\mathrm{W})$, opportunity $(\mathrm{O})$ and threat $(\mathrm{T})$. Strength and weakness are intern al factors obtained from the area, local people, and tourists, while opportunity and threat are external factors that positively and negatively affect area development. Data obtained from the analysis can be used as one perspective for development. Using strengths and opportu nities to manage the areas can increase the chances of success and reduce weaknesses and threats that also affect the area. Strengths and opportunities in this area are many such as geodiversity, biodiversity, history, culture, transportation and government assis tance. All parts can support each other to achieve good management. If the geosites have strong support and management this will promote geotourism and weaknesses and threats will be ameliorated and mitigated.

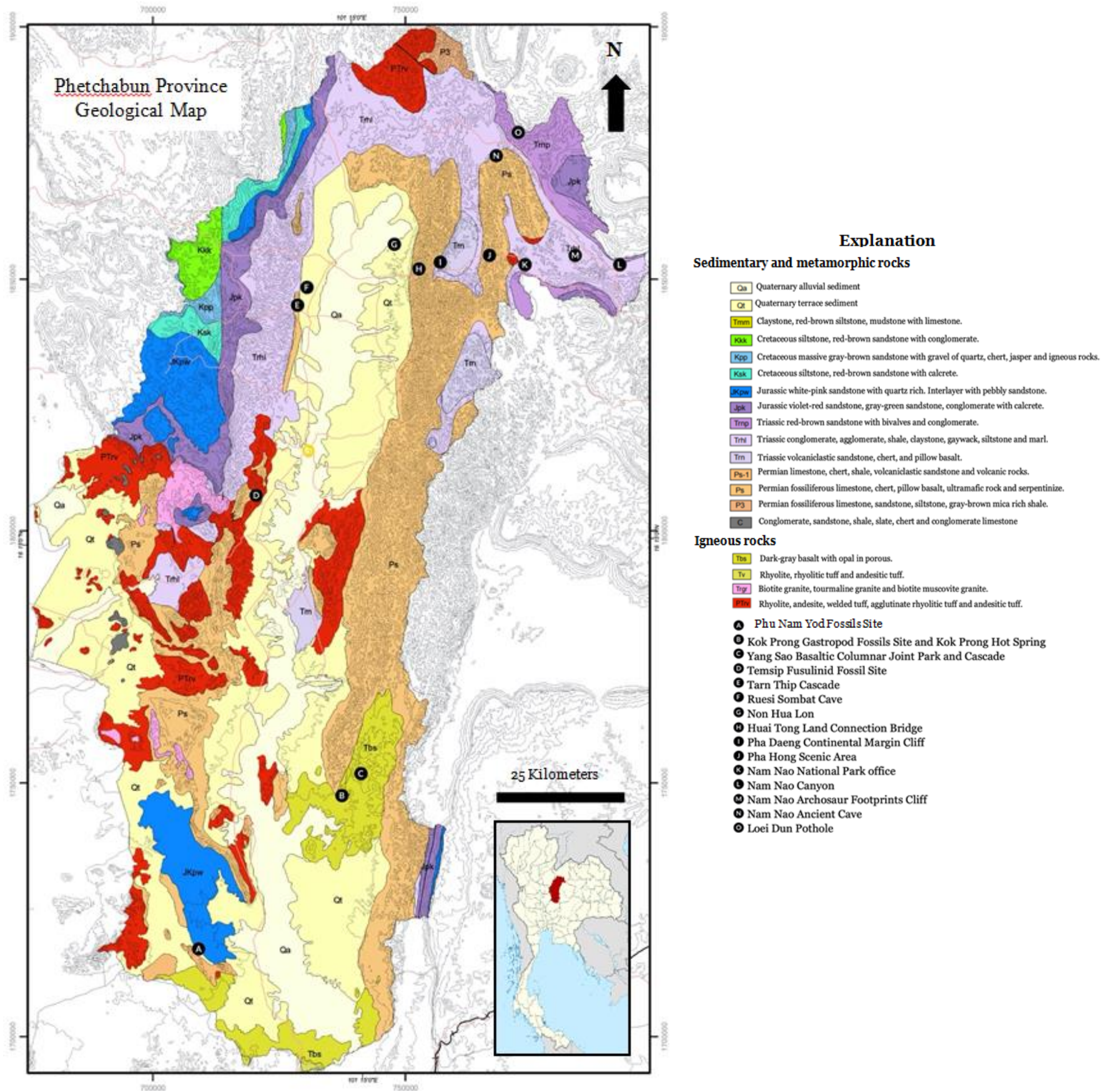

Figure 16. The geological map of study area in Phetchabun Province (modified from DMR, 2007b)

\section{Discussion for geotourism development}

The selected natural geological sites in Phetchabun Province have outstanding geodiversity distributed in four districts. The researchers distinguished the type of geosites and recommended travel routes in Figure 14. The geosites are protected by national parks, wildlife sanctuaries, local organizations and temples. Phetchabun geopark was established for overall geosite management with geological objects 
exhibited in Nong-Naree Science Park and a museum in Mueang district. Each geosites is far away from each other. Therefore, need to take time and should visit more than one day. To improve and promote public relations, Phetchabun geopark has produced tourist attraction books, postcards, geopark souvenirs and stickers that are sold in souvenir shops and cafes (Figure 15c-15d).

Geosite areas are separated into public and private sites. In the case of public sites, many areas are protected by government agencies. The purposes of geosites are conservation and utilization. Development limits depend on the approval of budgets from government organizations for public sites and landowners and stakeholders for private sites. Sustainable geotourism can be achieved by cooperation from all ownerships. Geotourism management should provide geological knowledge to tourists and use tourism tools to develop the attractions of geosites. The methods to achieve this aim are outlined (Ratanasuwongchai, 2010) as follows:

- Environment management consists of using economic and environmental indicators as tools to reflect problems occurring within the geopark. A zoning tool can be applied for suitable land management e.g. visitor center, parking, information labels, hiking trails, accommodation, and awareness of scenic and dangerous areas. A carrying capacity tool can maintain the level of resources potential and allocate tourism utilities and infrastructure appropriately without affecting the livelihood of local people.

- Community management consists of employment with local participation including tourism stakeholders and laws and regulations for the orderliness of the geological park

- Information management consists of information technology to promote tourism public relations such as geology learning media, museums and exhibitions, websites or social media fanpages. Tourism marketing is essential for success.

Petchabun Geopark is currently being assessed as a national geopark. The area has sufficient potential to be evaluated as a global geopark in the future.

\section{CONCLUSION}

The geosites in Phetchabun Province are varied and diverse, with potential to establish geotourism. The features consist of weathering and erosion sites, volcanic sites, tectonic plate sites, hot springs and fossil sites. The area is located at the meeting point of the Shan-Thai and Indochina plates, resulting in various rock and mineral formations, geomorphology and particular structures from geological processes. The basaltic columnar joint waterfall in Wichian Buri district is an outstanding geosite in Thailand. Identifying and assessing the potential of geosites is the first basic and essential step. This information can then be utilized for the development of geological tourism in line with the tourism industry in Thailand and global tourism trends.

\section{Acknowledgement}

The authors would like to thank the authorities of the Phetchabun Geopark, Department of Mineral Resource (DMR), National Park and Wildlife Sanctuary area of Thailand for their assistance. The authors thank the Mr. Wison Kositanont, Phetchabun Geopark Director for information and some illustration. Thanks, are also due to the Development and Promotion of Science and Technology Talents Project (DPST) for funding that supported this research.

\section{REFERENCES}

Allan, M. (2013). Geotourism: the potential of geotourism development in the United Arab of Emirates. Paper presented at The Second International Conference on Emerging Research Paradigms in Business and Social Sciences, Dubai, UAE.

Brilha, J. (2016). Inventory and Quantitative Assessment of Geosites and Geodiversity Sites: a Review. Geoheritage, 8, 119-134. https://doi.org/10.1007/s12371-014-0139-3

Brilha, J. (2018). Geoheritage: inventories and evaluation. Geoheritage: Assessment, Protection, and Management, Elsevier, Amsterdam, Netherlands, 69-86.

Bunopas, S., \& Khositanont, S. (2008). Did Shan-Thai twice marry Indochina and then India? a Review. Bulletin of Earth Sciences of Thailand (BEST), 1(1-2), 1-27.

Bunopas, S., \& Kong, T. (1982). Paleogeographic history of western Thailand and adjacent parts of south-east Asia: a plate tectonics interpretation. Department of Mineral Resources, Bangkok, Thailand.

Bunopas, S., \& Vella, P. (1983). Tectonic and geological evolution of Thailand. Paper presented at the Workshop on stratigraphic correlation of Thailand and Malaysia, Haad Yai, Thailand.

Charoensuk, J. (2016). Fracture system of columnar basalt in Amphoe Wichian Buri, Changwat Phethchabun. bachelor dissertation, Chulalongkorn University, Bangkok, Thailand.

Chonglakmani, C., \& Fontaine, H. (1990). The Lam Narai-Phetchabun region: A platform of Early Carboniferous to Late Permian age. In Proceedings of the development geology of Thailand into the year 2000, Bangkok, Thailand, 39-98.

Chonglakmani, C., \& Sattayarak, N. (1979). Geological map of Thailand on 1:250,000 scale: sheet Phetchabun Province, Bangkok, Thailand.

Ciftci, Y., \& Güngör, Y. (2016). Proposal for the standard presentation of elements of natural and cultural heritage within the scope of geopark projects. Bulletin of the Mineral research and exploration, 153, 223-238. https://doi.org/10.19076/mta.18476

Crawford, A.J., \& Panjasawatwong, Y. (1996). Ophiolites, ocean crust, and the Nan Suture in NE Thailand. International Symposium on Lithosphere Dynamics of East Asia, Taipei, Taiwan.

Davies, W.E., \& Morgan, I.M. (1991). Geology of cave. Government Printing Office, Washington DC, U.S.

Dawson, O. (1978). Deposition and diagenetic facies of Permian limestone from Saraburi, central Thailand. Paper presented at the Proceedings of the third regional conference on geology and minerals resources of Southeast Asia, Bangkok, Thailand.

Dowling, R. (2011). Geotourism's global growth. Geoheritage, 3, 1-13. https://doi.org/10.1007/s12371-010-0024-7

Dowling, R., \& Newsome, D. (2005). Geotourism. Butterworth-Heinemann, Oxford, England.

Ellis, M. (2006). The Caves of Nam Nao National Park, Phetchabun, Thailand. Shepton Mallet Caving Club Occasional Publication, Wells, Somerset, England.

Farsani, N.T., Coelho, C.O.A., Costa, C.M.M., \& Amrikazemi, A. (2014). Geoknowledge management and geoconservation via geoparks and geotourism. Geoheritage, 6,185-192. https://doi.org/10.1007/s12371-014-0099-7

Fontaine, H., \& Salyapongse, S. (2001). A Murgabian to Lower Triassic sequence exposed from Khao Tham Yai to Khao Pa Khi, Northeast Thailand: A preliminary report. Journal of the Geology Society of Thailand, 1, 43-47.

Fontaine, H., Salyapongse, S., Nguyen Duc, T., \& Vachard, D. (2002). The Permian of Khao Tham Yai area in Northeast Thailand. Paper presented at the The Symposium on Geology of Thailand, Bangkok, Thailand.

Gray, M. (2004). Geodiversity: valuing and conserving abiotic nature, John Wiley \& Sons, Chichester, England.

Gray, M. (2019). Geodiversity, geoheritage and geoconservation for society. International Journal of Geoheritage and Parks, 7, 226-236. https://doi.org/10.2139/ssrn.3502050

Gray, N.H. (1986). Symmetry in a natural fracture pattern: The origin of columnar joint networks. Computers \& Mathematics with Applications, 12(3-4), 531-545.

Gurel, E. (2017). Swot Analysis: A Theoretical Review. Journal of International Social Research, 10, 994-1006. https://doi.org/10.17719/jisr.2017.1832

Hada, S., Khosithanont, S., Goto, H., Fontaine, H., \& Salyapongse, S. (2015). Evolution and extinction of Permian fusulinid fauna in the Khao Tham Yai Limestone in NE Thailand. Journal of Asian Earth Sciences, 104, 175-184. https://doi.org/10.1016/j.jseaes.2014.03.007 
Hinthong, C. (1985). Upper Paleozoic system: the central plain and lower Phetchabun ranges, Geological Survey Division, Department of Mineral Resource, Bangkok, Thailand.

Hose, T.A. (1995). Selling the story of Britain's stone. Environmental Interpretation, 10, 16-17.

Hose, T.A. (2000). Geological Interpretation and Geoconservation Promotion for Tourists. In Geological Heritage: Its Conservation and Management, Sociedad Geologica de Espana/Instituto Technologico GeoMinero de Espana/ProGEO, Madrid, Spain, 127-146.

Hose, T.A. (2008). Towards a history of geotourism: definitions, antecedents, and the future. Geological Society, London, Special Publications, 300, 37-60.

Hose, T.A. (2011). The English origins of Geotourism (as a vehicle for geoconservation) and their relevance to current studies. Acta Geographica Slovenica, 51, 343-359. https://doi.org/10.3986/AGS51302

Khositanont, S., \& Khositanont, W. (2018). An introduction to the initiation of the Petchabun Geopark, Paper presented at the Regional Geoheritage Conference, Khon Kaen, Thailand.

Kosuwan, T. (1995). Evolution of sedimentary deposition and assessment of petroleum potential of the Wichian Buri sub-basin, Changwat Phetchabun, Master's degree dissertation, Chulalongkorn University, Bangkok, Thailand.

Lazzari, M., \& Aloia, A. (2014). Geoparks, geoheritage and geotourism: Opportunities and tools in sustainable development of the territory. Geojournal of Tourism and Geosites, 13, 8-9.

Limtrakun, P., Panjasawatwong, Y., \& Khanmanee, J. (2013). Petrochemistry and origin of basalt breccia from Ban Sap Sawat area, Wichian Buri, Phetchabun, central Thailand. Songklanakarin Journal of Science and Technology, 35(4), 469-482.

Metcalfe, I. (1999). Gondwana dispersion and Asian accretion: an overview. Gondwana Dispersion and Asian Accretion, Balkema, Rotterdam, Netherlands, 9-28.

Nazaruddin, D.A. (2020). Granite landforms of Samui Island (southern Thailand) from geoheritage, geoconservation and geotourism perspectives. International Journal of Geoheritage and Parks, 8(2), 75-86. https://doi.org/10.1016/j.ijgeop.2020.05.003

Newsome, D., Dowling, R., \& Leung, Y.F. (2012). The nature and management of geotourism: A case study of two established iconic geotourism destinations Tourism Management Perspectives, 2-3, 19-27. https://doi.org/10.1016/j.tmp.2011.12.009

Newsome, D., \& Dowling, R. (2017). Geoheritage and geotourism. In Geoheritage, Elsevier, Amsterdam, Netherlands, 305-321. https://doi.org/10. 1016/B978-0-12-809531-7.00017-4

Panizza, M. (2001). Geomorphosites: concepts, methods and examples of geomorphological survey. Chinese Science Bulletin, Suppl, 46, 4-6. https://doi.org/ 10.1007/BF03187227

Raksaskulwong, M. (2015). Update on Geothermal Utilizations in Thailand, Paper presented at the World Geothermal Congress, Melbourne, Australia.

Ratanasuwongchai, N. (2010). Ekkasān khamsōnn wichā kānphatthanā lēeng thōngthīeo (Prapprung khrang thī 5) [The study document on tourism attraction development subject, 5th ed.], Teaching documents, Department of Tourism and Hospitality Industry, Faculty of Humanities, Kasetsart University, Bangkok, Thailand.

Ruban, D.A. (2015). Geotourism - a geographical review of the literature. Tourism Management Perspectives, 15, 1-15. https:/doi.org/ 10.1016/j.tmp.2015.03.005

Saenyamoon, T., Loeuff, L.J., Suteethorn, V., Khansubha, S., \& Buffetaut, E. (2015). Vertebrate Footprints of South East Asia (Thailand and Laos): a Review. Paper presented at the International Conference on Geology, Geotechnology and Mineral Resources of Indochina (GEOINDO 2005), Khon Kaen, Thailand.

Sakha, P. (2018). Field Trip for geoheritage conservation in Phetchabun Province, Universiti Kebangsaan Malaysia Guidebook, Phetchabun, Thailand.

Shahhoseini, H., Modabberi, S., \& Shahabi, M. (2017). Study of factors influencing the attitude of local people toward geotourism development in Qeshm National Geopark, Iran. Geoheritage, 9, 3-48. https://doi.org/10.1007/s12371-015-0171-y

Singharajwarapan, S., \& Berry, R. (2000). Tectonic implications of the Nan Suture Zone and its relationship to the Sukhothai Fold Belt, Northern Thailand. Journal of Asian Earth Sciences - J ASIAN EARTH SCI, 18, 663-673. https://doi.org/10.1016/S1367-9120(00)00017-1

Singtuen, M., \& Won-In, K. (2018a). Geodiversity and geoconservation of the Chaiyaphum region in Thailand for sustainable geotourism planning. Geojournal of Tourism and Geosites, 22(1), 548-560. https://doi.org/10.30892/gtg.22223-310

Singtuen, M., \& Won-In, K. (2018b). Geological Perspective for Geotourism Development in Uthai Thani Province, Thailand. Journal of Environmental Management and Tourism, 9(5), 1003-1010. https://doi.org/10.14505//jemt.9.5(29). 12

Singtuen, M., \& Won-In, K. (2019). Geoheritage Sites and Geoconservation at Pha Chan - Sam Phan Bok Geopark, Ubon Ratchathani Province, Thailand. Geoconservation research, 2(1), 12-25. https://doi.org/10.30486/gcr.2019.664490

Singtuen, V., Gałka, E., Phajuy, B., \& Won-In, K. (2019). Evaluation and Geopark Perspective of the Geoheritage Resources in Chiang Mai Area, Northern Thailand. Geoheritage, 11(1), 1955-1972. https://doi.org/10.1007/s12371-019-00410-0

Sinsakul, S. (1992). Somdet phra thēp rattana rāt Sudā Sayām bọ̄om rāt kumārī sadet wana utthayān phæ mūangphī [H.R.H. Princess Maha Chakri Sirindhorn's went to The Phae Mueang Phi Park]. In Somdet phra thēp rattana rāt Sudā Sayām bōrom rāt kumārī kap ngān thōranīwitthayā [H.R.H. Princess Maha Chakri Sirindhorn's with Thailand geological work], Department of Mineral Resource, Thailand, 18-20.

Stoffelen, A., \& Vanneste, D. (2015). An integrative geotourism approach: bridging conflicts in tourism landscape research. Tourism Geographies, 17(4), 544-560. https://doi.org/10.1080/14616688.2015.1053973

Subtavewung, P., Raksaskulwong, M., \& Tulyatid, J. (2005). The Characteristic and Classification of Hot Springs in Thailand, Paper presented at the World Geothermal Congress, Antalya, Turkey.

Suthirat, C., Charusiri, P., Farrar, E., \& Clark, A.H. (1994). New 40Ar/39Ar geochronology and characteristics of some Cenozoic basalts in Thailand, Paper presented at The international Symposium on Stratigraphic Correlation of SE Asia, Bangkok, Thailand.

Wang, W., Mingzhu, L., \& Shan, H. (2009). Formation and development of stream potholes in a gorge in Guangdong. Journal of Geographical Sciences, 19(1), 118-128. https://doi.org/10.1007/s11442-009-0118-9

Wielchowsky, C.C., \& Young, J.D. (1985). Regional facies variations in Permian rocks of the Phetchabun fold and thrust belt, Thailand. Paper presented at the Conference on the Geology and Mineral Resource Development of Northeast Thailand, Khon Kaen University, Khon Kaen, Thailand.

Wimbledon, W.A.P. (1996). National site election, a stop on the road to a European Geosite List. Geologica Balcanica, 26, 15-27.

Zhong, J., Ni, J., Shen, X., Wang, G., \& Ji, G. (2002). Study of potholes in the lower reaches of the Yellow River. Acta Geologica Sinica, 76(2), 280-286.

*** DMR (Department of Mineral Resource). (2007a). Thōranīwitthayā prathēt Thai [The geology of Thailand], Dok Bia, Bangkok, Thailand.

*** DMR (Department of Mineral Resource). (2007b). Phōenthī thōranīwitthayā čhangwat phet būn [Phetchabun Province geological map], Map, Department of Mineral Resource, Bangkok, Thailand.

*** DMR (Department of Mineral Resource). (2009). Kān čhamnāek khèt phīa kānčhatkān dān thōranīwitthayā čhangwat phet būn [The area classification for geological and mineral resources management of Phetchabun Province], Chanwanit Printing, Bangkok, Thailand.

*** DMR (Department of Mineral Resource). (2020). Phǣnthī thọranīwitthayā lōi dan [Loei Dun Geological Map], Map, Geological Division, Department of Mineral Resource, Bangkok, Thailand.

*** Tourism Authority of Thailand. (2011). Phet būn [Phetchabun], Promotional Material Production Division, Marketing Services Department, Thailand. 